\title{
STUDI KOMPARATIF VARIASI KOMPETENSI KEPRIBADIAN GURU DENGAN MOTIVASI BELAJAR SISWA PADA MATA PELAJARAN IPS DI SMP NEGERI 2 SAWAN
}

\author{
Ros Indah Mareta Simanjuntak ${ }^{1}$, Ida Bagus Made Astawa ${ }^{2 *}$
}

Program Studi Pendidikan Geografi, Universitas Pendidikan Ganesha, Indonesia

\author{
A R T I C L E I N F 0 \\ Article history: \\ Received 9Agustus 2018 \\ Received in revised form \\ 6 November 2018 \\ Accepted 12 November 2018 \\ Available online 30 \\ November 2018

\section{Kata Kunci:} \\ Kompetensi Kepribadian \\ Motivasi Belajar Siswa \\ Keywords: \\ Personality Competence \\ Student Learning Motivation
}

\begin{abstract}
A B S T R A K
Penelitian ini bertujuan untuk: (1) Menganalisis ingkat kompetensi kepribadian guru, (2) Menganalisis ingkat Motivasi belajar siswa pada mata pelajaran IPS, (3) Menganalisis perbedaan variasi kompetensi kepribadian guru dengan motivasi belajar siswa pada mata pelajaran IPS. Berkenaan dengan itu penelitian dirancang sebagai penelitian deskriptif dengan studi populasi 50 orang siswa kelas IX SMP Negeri 2 Sawan. Pengumpulan data menggunakan angket yang selanjutnya dianalisis secara deskriptif analisis kualitatif dan kuantitatif. Hasil penelitian menunjukan bahwa (1) Adanya tingkat kompetensi kepribadian guru yang bervariasi di SMP Negeri 2 Sawan yaitu sangat tinggi dengan nilai 700, sedang 458 dan rendah 334, (2) Tingkat Motivasi belajar siswa pada mata pelajaran IPS dalam kategori sedang dengan skor sebanyak 3.200 (3) Tidak terdapat perbedaan variasi kompetensi kepribadian guru dengan motivasi belajar siswa pada mata pelajaran IPS di SMP Negeri 2 Sawan.
\end{abstract}

\section{A B S T R A C T}

This study aims to: (1) Analyze the level of teacher personality competence, (2) Analyze level Motivation of student learning on social studies subjects, (3) Analyze differences in teacher personality competency variations with student motivation in social studies subjects. In this regard, the study was designed as a descriptive study with a population study of 50 IX grade students of Sawan 2 Public Middle School. Data collection uses questionnaires which are then analyzed descriptively by qualitative and quantitative analysis. The results showed that (1) The competency level of teacher personalities that varied in Sawan Middle School 2 was very high with a value of 700, moderate 458 and low 334, (2) Level of Motivation for student learning in social studies in the moderate category with a score of 3,200 (3) There is no difference in the variation of the teacher's personal competencies with students' learning motivation in social studies subjects at Sawan 2 Public Middle School

\footnotetext{
* Corresponding author.

E-mail addresses: rosindahmareta@gmail.com, idabagusmadeastawa@yahoo.com
} 


\section{Pendahuluan}

Perkembangan ilmu dan teknologi yang semakin pesat di era globalisasi ini memunculkan persaingan dalam bidang pendidikan. Darsono (2001) mengungkapkan bahwa salah satu cara yang ditempuh untuk dapat bersaing dalam bidang pendidikan adalah melalui peningkatan mutu pendidikan. Upaya peningkatan mutu pendidikan dapat dilakukan melalui memperbaiki sarana prasarana, kurikulum dan sumber daya manusia. Peningkatan mutu pendidikan sangat erat kaitannya dengan belajar mengajar. Kegiatan belajar mengajar di sekolah merupakan kegiatan yang bersifat fundamental, sehingga dalam hal ini keberhasilan tercapainya tujuan pendidikan bergantung pada proses pembelajaran yang dialami siswa selaku peserta didik. Saputra (2012)mengungkapkan bahwa Proses Belajar Mengajar (PBM) merupakan aktivitas yang paling penting, dalam keseluruhan upaya pendidikan karena melalui proses inilah tujuan pendidikan akan tercapai dalam bentuk perubahan perilaku peserta didik.

Motivasi belajar yang ada pada diri siswa dipandang sebagai dorongan mental yang menggerakan dan mengarahkan perilaku termasuk perilaku belajar. Dimyati dan Mudjiono (2006) menyatakan bahwa siswa membutuhkan suatu dorongan belajar dalam proses belajar mengajar agar tercapainya tujuan pendidikan. Anni (2006) menyatakan bahwa motivasi belajar bukan hanya penting dalam mendorong siswa untuk belajar, namun motivasi belajar juga penting untuk memperlancar kegiatan belajar siswa di dalam kelas serta hasil belajar siswa. Siswa yang bermotivasi tinggi dalam belajar memungkinkan akan memperoleh hasil belajar yang tinggi pula, artinya semakin tinggi motivasinya, semakin intensitas usaha dan upaya yang dilakukan, maka semakin tinggi prestasi belajar yang diperolehnya (Hamdu, 2011).

Siswa membutuhkan sumber motivasi sebagai dorongan bagi mereka untuk memacu semangat siswa dalam mengikuti kegiatan belajar mengajar. Berkaitan dengan sumber motivasi, guru merupakan salah satu sumber motivasi utama bagi siswa dalam proses belajar mengajar. Guru memiliki peran untuk mengambil alih seluruh proses belajar mengajar di dalam kelas. Peran guru bukan hanya sekedar mentransfer ilmu, melainkan juga mendidik karakter siswa. Untuk dapat memperoleh hasil yang baik dalam suatu rangkaian kegiatan pendidikan dan pembelajaran, seorang guru dituntut untuk memiliki kualifikasi tertentu yang disebut juga kompetensi, yakni kemampuan seorang guru dalam melaksanakan kewajibannya secara layak dan tanggung jawab secara professional. Guru memiliki peranan terhadap pencapaian tujuan pembelajaran dimana guru tidak hanya dituntut untuk menguasai materi pembelajaran, namun guru juga dituntut untuk memiliki serta menampilkan kepribadian yang mampu memotivasi dan menginspirasi siswa dalam belajar. Bagi seorang guru telah menjadi kewajiban baginya untuk menguasai materi yang menjadi tanggung jawabnya, serta mampu menerapkan metode-metode pembelajaran guna melaksanakan tugasnya yang menjadi tujuan pokok dalam sebuah pembelajaran (Huda, 2017)

Hakim (2012) mengungkapkan bahwa kepribadian yang unggul dari seorang guru menjadi cara efektif untuk mengubah siswa dalam berbagai ranah, mulai dari ranah pengetahuan (kognitif), ranah sikap (afektif), dan ranah skill (psikomotor). Halhal yang berkaitan dengan motivasi, disipilin, tingkah laku sosial, prestasi dan hasrat 
belajar pada diri siswa dapat dipengaruhi oleh kepribadian guru. Penelitian Rosmiati (2016) menemukan bahwa terdapat hubungan yang signifikan antara sifat kepribadian guru IPS terhadap motivasi belajar siswa dalam proses pembelajaran. Faktor terpenting bagi seorang guru adalah kepribadiannya, kepribadian itulah yang akan menentukan apakah ia menjadi pendidik dan Pembina yang baik bagi peserta didiknya atau malah sebaliknya (Isrul, 2017). IPS bukan ilmu mandiri seperti halnya Ilmu-ilmu sosial lainnya, namun materi IPS menggunakan bahan ilmu-ilmu sosial yang dipilih dan disesuaikan dengan tujuan pengajaran dan pendidikan. Salah satu penyebab lahirnya IPS (social studies) disebabkan adanya keinginan dari ahli-ahli ilmu sosial dan pendidikan untuk memperkuat persatuan dan kesatuan bangsa (Ijtimaiyah, 2017). Pernyataan tersebut mengandung makna bahwa kepribadian seorang guru menjadi hal yang berperan penting dalam kegiatan belajar mengajar. Kepribadian guru dapat mempengaruhi kemampuan siswa termasuk dalam memotivasi siswa untuk belajar. Realita yang terjadi saat ini, ialah masih banyak guru yang belum menyadari pentingnya mengembangkan kompetensi kepribadian dalam menumbuhkan motivasi belajar siswa untuk belajar. Hal ini sangatlah berdampak bagi siswa karena motivasi belajar siswa menjadi rendah.

Pada proses belajar mengajar guru harus mampu memancarkan kepribadian yang baik agar disenangi oleh siswa. Kepribadian guru yang disenangi oleh siswa dapat mempengaruhi suasana belajar di dalam kelas, sehingga siswa tetap bisa mempertahankan motivasi belajarnya. Guru dapat mengandalkan kepribadiannya yang menyenangkan dalam penyampaian materi. Berkaitan dengan uraian di atas dilakukan observasi awal di SMP Negeri 2 Sawan. Hasilnya menunjukan bahwa masih banyak siswa yang kurang memiliki motivasi belajar, khususnya pada mata pelajaran IPS Terpadu. Berdasarkan observasi lapangan rendahnya motivasi belajar siswa terlihat saat proses belajar mengajar berlangsung, misalnya: siswa kurang memperhatikan guru, enggan menjawab pertanyaan, tertidur di dalam kelas saat pelajaran berlangsung, secara bergantian siswa pergi ke kamar kecil hingga tidak kembali sampai mata pelajaran IPS berakhir.

Berdasarkan hasil observasi awal yang telah dilakukan di SMP Negeri 2 Sawan, ada faktor yang melatarbelakangi terjadinya kondisi seperti di atas. Hasil wawancara dari beberapa siswa menunjukan bahwa terjadinya kondisi seperti uraian di atas di sebabkan karena terdapat beberapa kekurangan yang ditampilkan oleh guru dalam konteks kompetensi kepribadian yang dimiliki. Guru kurang bisa mengendalikan amarah ketika siswa melakukan kesalahan, guru seringkali memberikan hukuman hingga ancaman bagi siswa yang ribut atau konsentrasi belajarnya mulai melemah. Terbatasnya fasilitas pembelajaran di dalam kelas tidak diimbangi dengan kreativitas guru dalam memberikan daya tarik ke siswa dengan mengandalkan kepribadiannya yang menarik. Guru juga dinilai sering pilih kasih dalam menegur siswa ketika mereka ribut di dalam kelas. Kepribadian guru yang seperti ini secara tidak langsung menurunkan motivasi siswa untuk belajar.

Kemampuan kepribadian guru IPS dalam membelajarkan mata pelajaran IPS sangat dituntut untuk menumbuhkan motivasi belajar siswa. Hubungan antara kompetensi guru IPS dan motivasi belajar siswa salah satunya di tentukan oleh sifat 
kepribadian guru IPS. Rosmiati (2016) mengungkapkan bahwa tuntutan kepribadian guru IPS dalam memotivasi belajar siswa harus memiliki sifat-sifat mencakup: pertama, leksibilitas kognitif guru, yaitu sikap kognitif guru terhadap siswa dan sikap kognitif guru terhadap materi dan metode mengajar. Kedua, keterbukaan psikologis guru, yaitu kemampuan berkomunikasi dan berempati. Ketiga, sifat pribadi guru yang sabar, jujur, memiliki rasa humor dan ramah. Selain adanya tuntutan yang harus dimiliki oleh guru IPS sebagaimana yang telah diuraikan di atas, hal yang lebih penting, guru IPS seharusnya sudah tersertifikasi. Adanya sertifikasi guru, maka guru IPS diharapkan mampu secara personal memberikan motivasi bagi guru dalam meningkatkan kinerja guru khususnya dalam meningkatkan kualitas kompetensi kepribadian guru di sekolah baik sekolah negeri maupun swasta.

Penelitian ini dilakukan di SMP Negeri 2 Sawan karena adanya perbedaan kepribadian masing-masing guru IPS dalam memotivasi siswa belajar dimasing-masing kelasnya. Selain itu guru IPS tentu saja lebih mudah untuk mengaitkan nilai karakter yg harus dimiliki siswa yang berkaitan dengan materi yang sedang diberikan karena satusatunya mata pelajaran yang mengajarkan mengenai dinamika sosial dalam kehidupan hanya terdapat pada pelajaran IPS.

\section{Metode}

Penelitian ini adalah penelitian deskriptif komparatif dengan metode pengumpulan data observasi dan angket. Penelitian deskriptif adalah penelitian yang dilakukan untuk mengetahui keberadaan variabel mandiri, baik halnya satu variabel atau lebih tanpa membuat perbandingan atau dengan menghubungkan dengan variabel lainnya (variabel mandiri adalah variabel yang berdiri sendiri). Lokasi penelitian ini berada di desa Sawan yang terletak di Kabupaten Buleleng tepatnya beralamat di Desa Bungkulan Kecamatan Sawan. Sampel dalam penelitian ini adalah siswa kelas IX berjumlah 50 orang.

Jenis data yang digunakan dalam penelitian ini adalah data primer dan data sekunder. Data primer diperoleh langsung dari responden melalui kuisioner, sedangkan untuk data sekunder berasal dari data yang sudah ada. Teknik pengupulan data dalam penelitian ini menggunakan observasi dan angket. Hasil angket yang selanjutnya dianalisis menggunakan teknik analisis deskriptif kuantitatif dengan teknik Analysis of Varians (ANOVA) menggunakan bantuan aplikasi SPSS versi 16 for Windows.

\section{Hasil dan pembahasan}

\subsection{Kompetensi Kepribadian Guru IPS di SMP Negeri 2 Sawan}

Tabel 1. memaparkan mengenai kategori penilaian dengan interval sebanyak 120 yang dihasilkan dengan perhitungan skala likert. Interval skor keseluruhan responden dijadikan acuan untuk menentukan kategori tingkat kepribadian guru setelah memperoleh skor penilaian kompetensi kepribadian guru.

Tabel 1. 


\begin{tabular}{ll}
\multicolumn{2}{c}{ Interval Skor Keseluruhan Responden } \\
\hline SKOR & Kategori \\
\hline $151-270$ & SR \\
$271-390$ & R \\
$391-510$ & S \\
$511-630$ & T \\
$631-750$ & ST \\
\hline
\end{tabular}

Sumber : Pengolahan Data Primer, 2019

Berdasarkan penilaian melaui angket menyatakan hasil penelitian tentang tingkat kompetensi kepribadian guru IPS di SMP Negeri 2 Sawan menghasilkan variasi kompetensi kepribadian guru yaitu guru yang memiliki tingkat kompetensi kepribadian yang sangat tinggi, sedang dan rendah. Skor yang terdapat pada Tabel 2 merupakan jumlah keseluruhan data yang didapat dari angket kompetensi kepribadian guru. Rincian hasil penelitian tentang kompetensi kepribadian guru IPS di SMP Negeri 2 Sawan dapat dilihat pada Tabel 2.

Tabel 2.

Tingkat Kompetensi Kepribadian Guru

\begin{tabular}{lll} 
Guru & Kategori & Skor \\
\hline A & ST & 700 \\
B & S & 459 \\
C & R & 334
\end{tabular}

Sumber : Pengolahan Data Primer, 2019

Perbedaan kompetensi kepribadian ada karena terdapat aspek kompetensi kepribadian yang paling lemah dari guru tersebut. Aspek etos kerja terdiri dari 6 item pernyataan. Aspek pengembangan diri berkelanjutan terdiri dari 4 item pernyataan. Aspek toleransi terdiri dari 1 item pernyataan. Aspek akhlak mulia terdiri dari 2 item pernyataan. Aspek pengendalian diri terdiri dari 2 item pernyataan. Aspek terlemah dapat diketahui dari rata-rata skor berdasarkan jumlah masing-masing indikator dibagi dengan banyaknya item. Rincian mengenai skor kepribadian guru berdasarkan indikator dapat dilihat pada Tabel 3 sebagai berikut.

Tabel 3

Rincian Skor Kompetensi Kepribadian Guru

\begin{tabular}{llcccccc}
\hline \multirow{2}{*}{ No } & \multicolumn{1}{c}{ Indikator } & \multicolumn{3}{c}{ Skor } & \multicolumn{3}{c}{ Rata-rata } \\
\cline { 3 - 7 } & & Guru A & Guru B & Guru C & Guru A & Guru B & Guru C \\
\hline $\mathbf{1}$ & Etos Kerja & 281 & 200 & 117 & 46,8 & 33,3 & 11,7 \\
$\mathbf{2}$ & $\begin{array}{l}\text { Pengembangan diri } \\
\text { ber- kelanjutan }\end{array}$ & 184 & 119 & 89 & 46 & 29,8 & 22,5 \\
$\mathbf{3}$ & $\begin{array}{l}\text { Toleransi } \\
\quad\end{array}$ & 49 & 24 & 26 & 49 & 24 & 26
\end{tabular}




$\begin{array}{llllllll}4 & \text { Akhlak mulia } & 91 & 59 & 45 & 45,5 & 29,5 & 22,5 \\ \mathbf{5} & \text { Pengendalian diri } & 95 & 57 & 53 & 47,5 & 28,5 & 26,5\end{array}$

Sumber : Pengolahan Data Primer, 2019.

$$
\begin{array}{ll}
\text { Keterangan: } & \\
\text { SR } & =\text { Sangat rendah } \\
\text { R } & =\text { Rendah } \\
\text { S } & =\text { Sedang } \\
\text { T } & =\text { Tinggi } \\
\text { ST } & =\text { Sangat Tinggi }
\end{array}
$$

Berdasarkan rata-rata skor yang terdapat dari hasil perhitungan angket, aspek terlemah pada guru A terdapat pada akhlak mulia dengan rata-rata skor 45,5, sementara itu pada Guru B aspek terlemah adalah toleransi dengan rata-rata skor 24 dan Guru C aspek terlemah terletak pada pengembangan diri secara berkelanjutan dengan skor rata-rata 22,5. Perbedaan rata-rata pada kompetensi kepribadian guru di sebabkan dari guru IPS yang memiliki cara berbeda dalam bersikap, sehingga mendapatkan penilaian yang berbeda dari kepala sekolah maupun rekan sejawat.

Maka dari itu dapat disimpulakn bahwa guru IPS SMP Negeri 2 Sawan memiliki tiga variasi kepribadian guru yaitu guru dengan kepribadian sangat tinggi, guru dengan kepribadian tinggi, dan guru dengan kepribadian rendah yang dipengaruhi oleh faktor lemahnya akhlak mulia, toleransi, dan pengembangan diri.

\subsection{Motivasi Belajar Siswa Pada Mata Pelajaran IPS di SMP Negeri 2 Sawan}

Pengukuran tingkat motivasi belajar siswa pada mata pelajaran IPS di SMP Negeri 2 Sawan dilakukan dengan menggunakan angket yang ditujukan kepada siswa yang berjumlah 50 siswa/responden. Perhitungan tingkat motivasi belajar siswa pada mata pelajaran IPS ini menggunakan skala likert dengan jumlah pernyataan yang diajukan sebanyak 20 pernyataan. Perhitungan menggunakan skala likert ini menghasilkan rentan responden dengan interval sebanyak 800, sedangkan hasil perhitungan angket mengenai motivasi belajar siswa pada mata pelajaran IPS secara keseluruhan berjumlah 3.200 maka dari itu hasil motivasi belajar siswa terkategori sedang berdasarkan dengan Tabel 4. sebagai berikut.

Tabel 4.

Tingkat Motivasi Belajar Siswa

\begin{tabular}{ll}
\hline Skor & Kategori \\
\hline $1201-2000$ & SR \\
$2001-2800$ & R \\
$2801-3600$ & S \\
$3601-4200$ & T \\
\hline $4201-5000$ & ST \\
\hline
\end{tabular}


Rincian hasil angket motivasi belajar siswa pada mata pelajaran IPS dapat dilihat pada Tabel 5 sebagai berikut.

Tabel 5.

Hasil Angket Motivasi Belajar Siswa

\begin{tabular}{|c|l|c|l|}
\hline No & \multicolumn{1}{|c|}{ Indikator } & $\begin{array}{c}\text { Skor } \\
\text { Total }\end{array}$ & \multicolumn{1}{|c|}{$\begin{array}{c}\text { Skor Rata- } \\
\text { rata }\end{array}$} \\
\hline 1 & Durasi kegiatan & 673 & 168,2 \\
\hline 2 & Frekuensi kegiatan & 149 & 149 \\
\hline 3 & Presistensi tujuan kegiatan & 338 & 169 \\
\hline 4 & $\begin{array}{l}\text { Ketabahan, keuletan dan kemampuan } \\
\text { menghadapi kesulitan untuk mencapai tujuan }\end{array}$ & 934 & 157,8 \\
\hline 5 & Devosi dan pengorbanan & 175 & 175 \\
\hline 6 & $\begin{array}{l}\text { Tingkat aspirasi yang hendak dicapai dengan } \\
\text { kegiatan yang dilakukan }\end{array}$ & 470 & 156,7 \\
\hline 7 & Tingkat kualifikasi prestasi & 459 & 160,7 \\
\hline 8 & Arah sikap terhadap tujuan kegiatan & 147 & 147 \\
\hline
\end{tabular}

Sumber: Pengolahan Data Primer, 2019

Berdasarkan rata-rata yang terdapat dari hasil perhitungan angket, dapat diketahui bahwa skor rata-rata durasi kegiatan siswa adalah 168,2, skor rata-rata frekuensi kegiatan adalah 149, skor rata-rata presistensi tujuan kegiatan 169, skor ratarataketabahan, keuletan dan kemampuan menghadai kesulitan untuk mencapai tujuan adalah 157,8 skor rata-rata devosi dan pengorbanan adalah 175 , skor rata-rata tingkat aspirasi yang hendak dicapai dengan kegiatan yang dilakukan adalah 156,7 , skor rataratatingkat kualifikasi prestasi adalah 160,7, skor rata-rata arah sikap terhadap tujuan adalah 147.

Maka dari itu dapat diketahui bahwa tingkat motivasi siswa yang rendah disebabkan karena ada aspek paling lemah pada motivasi siswa dalam belajar. Aspek paling lemah pada motivasi belajar siswa terdapat pada indikator yang berkaitan dengan arah sikap siswa terhadap tujuan kegiatan pembelajaran dengan skor rata-rata 147 dan frekuensi siswa dalam mengikuti pembelajaran IPS di dalam kelas dengan perolehan skor rata-rata 149.

\subsection{Hubungan Kompetensi Kepribadian Guru dengan Motivasi Belajar Siswa pada Mata Pelajaran IPS di SMP Negeri 2 Sawan}

Pengukuran hubungan kompetensi kepribadian guru dengan motivasi belajar siswa pada mata pelajaran IPS dilakukan dengan menggunakan angket. Angket tersebut berkaitan dengan motivasi belajar siswa terhadap masing-masing guru IPS yang pernah mengajar siswa tersebut. Hasil skor keseluruhan akan di rata-rata, rata-rata didapatkan dengan cara menghitung jumlah keseluruhan skor dibagi dengan jumlah item pernyataan. Hasil dari pengisian angket menunjukan bahwa rata-rata skor motivasi belajar siswa paling tinggi yaitu ketika melaksanakan proses belajar mengajar bersama guru A. Namun, meskipun motivasi belajar tertinggi terdapat pada guru A, masih ditemukan aspek motivasi belajar siswa yang rendah pada masing-masing kepribadian 
guru IPS. Hasil rata-rata angket motivasi belajar siswa terhadap guru IPS dapat dilihat pada Tabel 6. sebagai berikut.

Tabel 6.

Hasil rata-rata angket motivasi belajar siswa terhadap guru IPS

\begin{tabular}{|c|l|c|c|c|c|c|c|}
\hline \multirow{2}{*}{ No } & \multicolumn{1}{|c|}{ Indikator } & \multicolumn{3}{|c|}{ Skor } & \multicolumn{3}{c|}{ Rata-rata } \\
\cline { 3 - 8 } & $\begin{array}{c}\text { Guru } \\
\text { A }\end{array}$ & $\begin{array}{c}\text { Guru } \\
\text { B }\end{array}$ & $\begin{array}{c}\text { Guru } \\
\text { C }\end{array}$ & $\begin{array}{c}\text { Guru } \\
\text { A }\end{array}$ & $\begin{array}{c}\text { Guru } \\
\text { B }\end{array}$ & $\begin{array}{c}\text { Guru } \\
\text { C }\end{array}$ \\
\hline 1 & Durasi kegiatan & 800 & 794 & 765 & 200 & 198,5 & 191,5 \\
\hline 2 & $\begin{array}{l}\text { Frekuensi } \\
\text { kegiatan }\end{array}$ & 108 & 105 & 105 & 108 & 205 & 205 \\
\hline 3 & $\begin{array}{l}\text { Presistensi } \\
\text { trjuan kegiatan }\end{array}$ & 206 & 203 & 200 & 203 & 201,5 & 185 \\
\hline 4 & $\begin{array}{l}\text { Ketabahan, } \\
\text { keuletan dan } \\
\text { kernampuan } \\
\text { menghadapi } \\
\text { kesulitan untuk } \\
\text { mencapai tujuan }\end{array}$ & 924 & 885 & 824 & 209 & 196,8 & 191 \\
\hline 5 & $\begin{array}{l}\text { Devosi dan } \\
\text { pengorbanan }\end{array}$ & 207 & 201 & 190 & 207 & 201 & 200 \\
\hline 6 & $\begin{array}{l}\text { Tingkat aspirasi } \\
\text { yang hendak } \\
\text { dicapai dengan } \\
\text { kegiatan yang } \\
\text { dilakukan }\end{array}$ & 407 & 404 & 389 & 202,3 & 201,3 & 202,3 \\
\hline 7 & $\begin{array}{l}\text { Tingkat } \\
\text { kualifikasi } \\
\text { prestasi }\end{array}$ & 411 & 407 & 380 & 203,7 & 202,3 & 196,6 \\
\hline 8 & $\begin{array}{l}\text { Arah sikap } \\
\text { trerhadap tujuan } \\
\text { kegiatan }\end{array}$ & 110 & 110 & 101 & 210 & 210 & 185 \\
\hline Total Skot & 3173 & 3109 & 2954 & & & \\
\hline Sumber: Data Primer yang diolah, 2019 & & & & & \\
\hline
\end{tabular}

Berdasarkan Tabel 6. motivasi belajar siswa pada guru A menunjukan total skor sebesar 3.137, berdasarkan Tabel 4.6 motivasi belajar tergolong sedang. Aspek motivasi belajar terlemah terhadap proses belajar mengajar dengan guru A terdapat pada frekuensi kegiatan, siswa dalam mengikuti pembelajaran dengan rata-rata perolehan skor sebanyak 108.

Berkaitan dengan itu berdasarkan Tabel 6. motivasi belajar siswa pada guru B menunjukan total skor sebesar 3.109, berdasarkan Tabel 4 motivasi belajar siswa tergolong sedang. Aspek terlemah motivasi belajar siswa dengan guru B terdapat pada aspek ketabahan, keuletan dan kemampuan menghadapi kesulitan untuk mencapai tujuan dengan rata-rata skor 196,8. Berdasarkan Tabel 6. motivasi belajar siswa pada guru C menunjukan total skor sebesar 2.954, berdasarkan Tabel 4. motivasi belajar tergolong sedang. Aspek motivasi belajar terlemah terhadap guru C terdapat pada presistensi tujuan kegiatan dan Arah sikap siswa terhadap tujuan kegiatan belajar mengajar yang memiliki skor rata-rata 185 .

Adapun untuk mengetahui terdapat atau tidaknya perbedaan dari kompetensi kepribadian guru dengan motivasi belajar siswa kelas IX pada mata pelajaran IPS di SMP Negeri 2 Sawan, dilakukan uji anova satu jalur. Hasil uji anova satu jalur dapat dilihat pada Tabel 7. sebagai berikut:

Tabel 7.

Uji Anova Satu Jalur

\begin{tabular}{lccccc}
\hline & $\begin{array}{c}\text { Sum of } \\
\text { Squares }\end{array}$ & Df & $\begin{array}{c}\text { Mean } \\
\text { Square }\end{array}$ & F & Sig. \\
\hline Between & 198.893 & 2 & 99.447 & 2.571 & 080 \\
\hline
\end{tabular}




\begin{tabular}{|c|c|c|c|}
\hline $\begin{array}{l}\text { Groups } \\
\text { Within } \\
\text { Groups }\end{array}$ & 5685.380 & 147 & 38.676 \\
\hline Total & 5884.273 & 149 & \\
\hline
\end{tabular}

Data di atas menunjukan bahwa $\mathrm{F}$ hitung yaitu 2,571, sedangkan penentuan $\mathrm{F}$ tabel dapat dihitung dengan $\mathrm{N}$-df yaitu 50-2 $=48$, F tabel $=4,040$ Taraf signifikansi dalam penelitian ini adalah 5\%. Sesuai dengan kriteria ANOVA satu jalur dimana 2,571 < 4,040 maka H0 diterima. Hasil ini menunjukan bahwa tidak adanya perbedaan kompetensi kepribadian guru dengan motivasi belajar siswa kelas IX pada mata pelajaran IPS di SMP Negeri 2 Sawan.

\section{Simpulan dan saran}

Berdasarkan hasil penelitian dan pembahasan maka dapat disimpulkan sebagai berikut. Kompetensi kepribadian guru IPS menunjukkan hasil yang berbeda. Ketiga guru yang diteliti memliki kompetensi kepribadian yang berbeda terdiri dari kompetensi kepribadian sangat tinggi dengan skor 700 untuk guru A, sedangkan kompetensi kepribadian sedang dengan skor 459 untuk guru B dan kompetensi kepribadian terendah dengan skor 334 untuk guru C. Motivasi belajar siswa pada mata pelajaran IPS menunjukan hasil sedang dengan perolehan skor 3.200 serta rentan interval sebanyak 800. Hal ini dibuktikan dengan hasil perhitungan angket yang diisi oleh siswa. Hasil analisis data menunjukan bahwa $\mathrm{F}$ hitung yaitu 2,571, dengn penentuan $\mathrm{F}$ Tabel $\mathrm{N}$-df yaitu 50-2 $=48, \mathrm{~F}$ tabel $=4,040$ Sesuai dengan kriteria ANOVA satu jalur dimana $2,571<4,040$ maka H0 diterima. Hasil ini menunjukan bahwa tidak terdapat perbedaan dari variasi kompetensi kepribadian guru dengan motivasi belajar siswa.

Berdasarkan penelitian yang dapat disarankan adalah 1) Bagi guru IPS SMP Negeri 2 Sawan, kompetensi kepribadian perlu dikembangkan serta ditingkatkan agar berada pada tingkat yang lebih tinggi. Hal ini bertujuan agar kompetensi kepribadian yang dimiliki guru diharapkan dapat membangun motivasi siswa untuk mengikuti mata pelajaran IPS. 2) Bagi siswa SMP Negeri 2 Sawan, motivasi belajar siswa harus ditingkatkan terkhususnya pada mata pelajaran IPS. Motivasi siswa yang baik pada pelajaran IPS akan membawa siswa memiliki pengetahuan yang luas mengenai kehidupan yang bermoral dan bermasyarakat.

\section{Daftar Rujukan}

Anni, C. T. (2006). Psikologi Belajar. Semarang: UPT UNNES Press.

Darsono. (2001). Belajar dan Pembelajaran. Semarang: IKIP Press.

Dimyati dan Mudjiono. (2006). Belajar dan Pembelajaran. Jakarta: PT. Raja Grafindo Persada.

Hakim, L. M. (2012). The Great Teacher: Mendedah Aspek-Aspek Kepribadian Guru Ideal Dan Pembentukan Perilaku Siswa. Jurnal Pendidikan Dompet Dhuafa, 2(1).

Hamdu, G. dan L. A. (2011). Pengaruh Motivasi Belajar Siswa Terhadap Prestasi Belajar 
IPA di Sekolah Dasar. Jurnal Penelitian Pendidikan, 12(1).

Huda, M. (2017). Kompetensi Kepribadian Guru dan Motivasi Belajar Siswa. Jurnal Penelitian, 11(2), 245.

Ijtimaiyah. (2017). Pengembangan Materi Ajar Ilmu Pengetahuan Sosial. Jurnal Program Studi Pendidikan Ilmu Sosial, 1(1).

Isrul. (2017). “Belajar Peserta Didik di SMP Negeri 3 Matrisompe." Biology Science, 6(1).

Rosmiati, J. dan H. (2016). Hubungan Sifat Kepribadian Guru IPS Terhadap Motivasi Belajar Siswa dalam Proses Pembelajaran pada MTs Negeri di Kota Palu. 4(7).

Saputra, V. dan A. Y. (2012). Kepribadian Dosen Yang Berpengaruh Terhadap Prestasi Belajar. Dinamika Manajemen, 3, 91-100. 